\title{
Invasive plants and their escape from root herbivory: a worldwide comparison of the root-feeding nematode communities of the dune grass Ammophila arenaria in natural and introduced ranges
}

\author{
W.H. van der Putten ${ }^{1, *}$, G.W. Yeates ${ }^{2}$, H. Duyts ${ }^{1}$, C. Schreck Reis ${ }^{3} \&$ G. Karssen ${ }^{4}$ \\ ${ }^{1}$ Netherlands Institute of Ecology (NIOO-KNAW), Department of Multitrophic Interactions, P.O. Box \\ 40, 6666 ZG Heteren, The Netherlands; ${ }^{2}$ Landcare Research, Private Bag 11-052 Palmerston North, New \\ Zealand; ${ }^{3}$ IMAR, Departamento de Botânica, Universidade de Coimbra, 3000 Coimbra, Portugal; ${ }^{4}$ Plant \\ Protection Service, Nematology section, P.O. Box 9102, 6700 HC Wageningen, The Netherlands; *Author \\ for correspondence (e-mail: putten@nioo.knaw.nl)
}

Received 27 February 2004; accepted in revised form 7 July 2004

Key words: Ammophila arenaria, Ammophila breviligulata, biotic resistance hypothesis, enemy escape hypothesis, feeding specialist, invasive plant, root herbivore, soil pathogen

\begin{abstract}
Invasive plants generally have fewer aboveground pathogens and viruses in their introduced range than in their natural range, and they also have fewer pathogens than do similar plant species native to the introduced range. However, although plant abundance is strongly controlled by root herbivores and soil pathogens, there is very little knowledge on how invasive plants escape from belowground enemies. We therefore investigated if the general pattern for aboveground pathogens also applies to root-feeding nematodes and used the natural foredune grass Ammophila arenaria as a model. In the late 1800 s, the European $A$. arenaria was introduced into southeast Australia (Tasmania), New Zealand, South Africa, and the west coast of the USA to be used for sand stabilization. In most of these regions, it has become a threat to native vegetation, because its excessive capacity to stabilize windblown sand has changed the geomorphology of coastal dunes. In stable dunes of most introduced regions, A. arenaria is more abundant and persists longer than in stabilized dunes of the natural range. We collected soil and root samples and used additional literature data to quantify the taxon richness of root-feeding nematodes on $A$. arenaria in its natural range and collected samples from the four major regions where it has been introduced. In most introduced regions $A$. arenaria did not have fewer root-feeding nematode taxa than the average number in its natural range, and native plant species did not have more nematode taxa than the introduced species. However, in the introduced range native plants had more feeding-specialist nematode taxa than $A$. arenaria and major feeding specialists (the sedentary endoparasitic cyst and root knot nematodes) were not found on A. arenaria in the southern hemisphere. We conclude that invasiveness of $A$. arenaria correlates with escape from feeding specialist nematodes, so that the pattern of escape from root-feeding nematodes is more alike escape from aboveground insect herbivores than escape from aboveground pathogens and viruses. In the natural range of $A$. arenaria, the number of specialist-feeding nematode taxa declines towards the margins. Growth experiments are needed to determine the relationship between nematode taxon diversity, abundance, and invasiveness of $A$. arenaria.
\end{abstract}




\section{Introduction}

Invasive species are a major threat to biodiversity and ecosystem processes in native communities (Rejmanek and Richardson 1996) and they may cause significant costs to the environment, economy and public health (Pimentel 2002). Biological invaders include plants and animals (Liebhold et al. 1995) that have been introduced to novel regions intentionally or unintentionally. Relatively few introduced species become invasive, and although there are a number of features that characterize potential invaders, invasiveness is difficult to predict (Williamson 1996). Some strategies to control invasive species are based on the enemy escape hypothesis, which assumes invasiveness to be due to the release of invasive species from their natural enemies (Keane and Crawley 2002). Recent overviews on invasive plants (Mitchell and Power 2003) and animals (Torchin et al. 2003) have demonstrated that in their introduced ranges exotic species indeed have fewer pathogens, parasites, or viruses than in their natural range. The introduced species also have fewer of these natural enemies than do similar, native species in the introduced range. However, there are few studies on plant escape from root-feeding insects and even fewer on escape from soil pathogens or root-feeding nematodes.

Root herbivores and soil pathogens are important regulators of spatial and temporal changes in the composition of natural vegetation (Yeates 1999; Wardle 2002; Bever 2003; van der Putten 2003). Evidence is accumulating that soil pathogens and root herbivores play important roles in controlling plant abundance (Klironomos 2002), plant species diversity (Bever 1994; Packer and Clay 2000, 2002; De Deyn et al. 2003), and vegetation succession (Brown and Gange 1992; van der Putten et al. 1993; De Deyn et al. 2003). Root-feeding insects may cause dramatic decline of plant populations (Blossey and Hunt-Joshi 2003), while effects of root-feeding nematodes vary from marked, generalized reduction in plant production (Stanton 1988), to localized damage patches (Verschoor et al. 2001), and their effects may depend on interactions with, for example, pathogenic soil fungi (De Rooij-van der Goes 1995; van der Putten and van der Stoel 1998). There have been biological control programs involving release of root-feeding insects, for example to control Knapweed (Centaurea maculosa) in the USA (Clark et al. 2001a, b), although such introduced enemies also can exert negative effects on other plants (Callaway et al. 1999). However, we know of no programs involving the release of soil pathogens or root-feeding nematodes in order to control plant invasions; the few Anguinidae (Nematoda: Tylenchida) tested parasitise aboveground plant structures (Robinson et al. 1978).

Few studies on biological invasions have tested how these effects may have arisen (Levine et al. 2003). Klironomos (2002) showed that five plant species introduced to North America did not accumulate soil pathogens as rapidly as did rare plants when grown in repeated monocultures. However, this study did not include the response of the introduced plants in their natural soils. Wide spacing of North American Prunus serotina (Black cherry) trees in North American forests correlates with high seedling mortality in soil from underneath parent trees (Packer and Clay 2000, 2002). Such mortality did not occur in the non-native range, where $P$. serotina has much higher abundance, suggesting that invasiveness of this tree is due to escape from soil pathogens (Reinhart et al. 2003).

There are few studies on the nematode communities of invasive plants. Densities of rootfeeding nematodes were higher on the roots of the woody legume mesquite (Prosopis glandulosa) in its original range than in recently invaded desertified perennial grasslands in the Chihuahuan desert, USA (Virginia et al. 1992). In New Zealand the invasive weed Tradescantia fluminensis had seven additional taxa of nematodes compared to reference locations without this invading species (Yeates and Williams 2001). In South African coastal foredunes, introduced marram grass (Ammophila arenaria) shared a number of root-feeding and non-root-feeding nematode species with the indigenous beach grass Elymus distichus and the indigenous foredune grass Erharta villosa, while all root-feeding species were rather unspecialized (Knevel et al. 2004). None of these studies, however, included a comparison with nematodes on the introduced plant species in their entire natural and introduced ranges.

We compare the root-feeding nematode community of the natural foredune grass $A$. arenaria 
in its natural range with that in areas where the grass has been introduced for the stabilization of coastal sand dunes. A. arenaria occurs naturally in north-western Europe and along the Mediterranean coast (Huiskes 1979). Because A. arenaria is intensively planted for sand stabilization in coastal dunes, the history of introduction and spread has been well recorded. In the second half of the 19th century it was introduced to the USA (1868, where it had been introduced from Australia; Wiedemann and Pickart 1996), South Africa (1870s; Hertling and Lubke 2000), southeastern Australia/Tasmania (before 1868; Wiedemann and Pickart 1996), and New Zealand (1873; Owen 1996). The plant was introduced as seeds (Hertling and Lubke 1999) which may have enabled escape from root-feeding nematodes, since these are usually not vertically transmitted. In southeast Australia (Tasmania) and the USA, $A$. arenaria has become an invasive weed (Heyligers 1985, Buell et al. 1995), in New Zealand A. arenaria is considered a weed (Owen 1996), while in South Africa, the invasive potential is supposed to be limited by water supply (Hertling and Lubke 2000). In the USA, A. arenaria has been responsible for changing the geomorphology of the coastal dunes, which is a major reason of its negative effects on native plant species (Wiedemann and Pickart 1996). In stabilized non-native dunes, A. arenaria is more abundant and more persistent than in stabilized dunes of its natural range.

The similar history, date, and mode of introduction of $A$. arenaria to all these new territories in temperate regions of the northern and southern hemispheres makes it a suitable model for comparing the taxon richness of root-feeding nematode communities. We grouped nematodes as feeding specialists and feeding generalists (Yeates et al. 1993), which allows comparison with aboveground feeding-specialist invertebrate herbivores on invasive plants. Jobin et al. (1996) and Memmott et al. (2000) observed less feedingspecialist aboveground insects on invasive plant species. We test the hypotheses that in its natural range (1) A. arenaria has more taxa of root-feeding nematodes than in its introduced range (Mitchell and Power 2003; the taxon diversity hypothesis), (2) $A$. arenaria has more specialist feeders (i.e. sedentary, endoparasitic nematodes) than in the introduced range (Jobin et al. 1996; Memmott et al. 2000; the feeding-specialist hypothesis), and that (3) in its introduced range, A. arenaria has fewer root-feeding nematode taxa than do similar native species (Mitchell and Power 2003; the native species hypothesis). In addition, since the observed nematode diversity may depend on sampling intensity, we also investigated the effect of sampling intensity in one natural and in one introduced region.

\section{Materials and methods}

\section{Terminology}

\section{Geography}

We distinguish the natural range (northwestern and Mediterranean Europe) and the introduced range consisting of four regions: one on the northern hemisphere (USA) and three on the southern hemisphere (South Africa, Australia/ Tasmania, and New Zealand). Within the native range and each introduced region, we have collected samples from a number of locations. Within each location, five samples were collected (only three from South Africa), which were pooled because these were pseudoreplicates; the locations were the true replicates. Locations (abbreviations) examined in the present study are: Kampinos dunes Poland (Pl), Tentsmuir Point, Fife, Scotland (S), Voorne, Netherlands $(\mathrm{N})$, São Jacinto, Portugal north (Pn), Sado Estuary, Portugal south (Ps), two sites in the Camarque, Mediterranean France $(\mathrm{Fa}$ and $\mathrm{Fb}$ ) in Europe, Sunset beach road, Oregon (SR), Sunset beach road, Oregon (SB), South Salmon creek, California (SC), Humboldt bay, California (HB) in USA, De Mond (D), Blue bay (Bb), Sedgefield (Sf), Klein Brak (K1), Koeberg (Ko), Kleinmonde field (Kf), Kleinmonde slack (Ks), Table View (TV) in South Africa, Patea (P), Castlecliff (C), Himatangi (H), Sumners (S), Taylors (T), Birdlings (B) in New Zealand, and prograding (P) and degrading (D) sites in Tasmania.

\section{Nematodes}

In case of literature data, we used the list of nematode genera or species provided. We distinguished sedentary endoparasites, migratory 
endoparasites, and ectoparasites according to Yeates et al. (1993), and considered semi-endo ectoparasites as ectoparasites. Sedentary endoparasites were considered as feeding specialists, because of their ability to initiate feeding structures within plant roots.

\section{Collection of samples and identification of nematodes}

Soil samples were collected from locations in Europe (the natural range) and from regions where $A$. arenaria had been introduced. In all regions, the nematode community was assessed in the active growth season. In Europe and the USA, we sampled in August, and in South Africa and Tasmania in October, and for New Zealand in May-June. The locations in the Netherlands and at Himatangi Beach in New Zealand were sampled year-round, and we used these data to determine possible underestimation arising from a single sampling.

From each sampling location, 300-500 g samples of soil and roots were collected from the 1-year old root layer of five $A$. arenaria plants. When there were similar native plant species around, soil and root samples from these native species were collected similar as from $A$. arenaria. In mobile (yellow) dunes, $A$. arenaria plants are buried each year by windblown beach sand, followed by shoot elongation and the formation of new roots (de Rooij-van der Goes et al. 1995). The 1-year old root layer is usually well colonized by nematode taxa (van der Stoel et al. 2002). At each sampling location, the five replicates (three in South Africa) were collected from the outer edge of single tussocks, $25 \mathrm{~m}$ apart along a transect parallel to the shoreline. Additional data were obtained from the literature: Scotland (Wall et al. 2002), Poland (Kisiel 1970), The Netherlands (van der Stoel et al. 2002), and New Zealand (Yeates 1967, 1968). Root-feeding nematode species were categorized into feeding groups as was done for the sites that we have sampled ourselves and the data from each individual survey (one in Scotland and Poland and six in New Zealand) were considered as replicates.

The soil/root samples were transported by air. This procedure may have reduced the abundance of nematodes in the samples, so that we decided not to perform quantitative comparison of abundance among sampling locations. Upon arrival, the samples were stored at $4{ }^{\circ} \mathrm{C}$ until nematodes were collected from the sand using an Oostenbrink elutriator and from the roots by wet funnel extraction. Roots were also inspected for the presence of cysts (females of Heterodera spp.) and root knots (induced by females of Meloidogyne spp.).

The level of nematode identification depended on the availability of suitable keys or the presence of appropriate life stages (e.g. cysts). For each location, we counted all root-feeding nematode taxa. Identifications that have been made to species level have been mentioned as such; In the cases where we did not identify to species, we have aggregated by genus for the different locations and regions, unless we were sure that the species should be different. In the latter case, we designated them as Genus $a$, $b$, etc. This procedure was designed to have the least impact on our analyses, and to reduce the size of tables.

\section{Data analysis}

To compare nematode species richness associated with $A$. arenaria in natural and introduced regions (hypothesis 1), we compared the number of nematode taxa present in a region by one-way ANOVA with unequal number of replicates, after testing homogeneity of variances. The numbers of root-feeding nematode taxa present at sampling locations (for example Scotland, Poland, The Netherlands, Portugal north, Portugal south, and southern France) within region (Europe) were used as replicates. In order to test if $A$. arenaria has more specialist feeders (i.e. sedentary, endoparasitic nematodes) than in the introduced range (hypothesis 2) we performed the same analysis for feeding specialist (sedentary endoparasites) and generalist (ectoparasites and migratory endoparasites) feeding types using the classification by Yeates et al. (1993).

To test if in its introduced range, $A$. arenaria has fewer root-feeding nematode taxa than do similar native species (hypothesis 3), $t$-tests were applied to determine if the difference between the number of root-feeding nematode taxa on the introduced $A$. arenaria and numbers of taxa on 
the native plant species would be less than zero $(P<0.05)$. If the test resulted in a non-significant $P$-value $A$. arenaria had equal or higher number of nematode taxa than similar native plant species, so that hypothesis 3 should be rejected. In that case, the average of the data points would end up on or above the 1:1 line in a graph where number of nematode taxa of native plant species ( $x$-axis) are plotted against the numbers on $A$. arenaria ( $y$-axis). We performed this test for all nematode taxa, as well as for number of taxa of specialist and generalist feeding types, and did a similar test for the native region.

\section{Results}

Comparing nematode taxon diversity on Ammophila arenaria between natural and introduced ranges

The plant-feeding nematodes identified from the root zone of A. arenaria in natural and introduced regions are listed in Table 1. There were 6 suborders, 13 families, and 17 genera in the total data set. The number of species could not be accurately determined, as it was not possible to identify all genera to species. The number of nematode taxa differed significantly among ranges (Figure 1; oneway ANOVA $F=5.44, \mathrm{df}=4, P=0.0034$ ). In New Zealand, the total number of nematode taxa was significantly lower $(P<0.05)$ than in Europe, the USA and South Africa, while there were no significant differences in number of nematode taxa among Europe, USA, South Africa, and Tasmania $(P>0.05)$. Therefore, based on our level of identification the diversity of root-feeding nematodes on A. arenaria was not particularly higher in its natural range (Europe) than in most introduced regions (except New Zealand), not supporting the taxon diversity hypothesis (1).

There were significantly fewer taxa of feeding specialist nematodes in South Africa, New Zealand and Tasmania than in Europe and the USA $(P<0.05$; one-way ANOVA $F=15.03, \mathrm{df}=4$, $P<0.0001$; means not shown). This result supports the feeding-specialist hypothesis (2), but only for the non-native regions in the southern Hemisphere, where no feeding specialists were detected in the root zone or on the roots of $A$. arenaria. On average the number of feeding specialist nematodes on $A$. arenaria in the USA was not different $(P>0.05)$ from that in the natural range, Europe. However, within the native range, there were fewer specialist root feeder taxa in the margins (Portugal and Mediterranean France in the south and Poland in the north) than in the centre (The Netherlands and Scotland; see Table 2). In the Netherlands and Scotland, there were two genera of feeding-specialist (sedentary endoparasitic) nematodes present (Heterodera and Meloidogyne), while in Portugal and southern France, there was only one genus of sedentary endoparasites (Meloidogy$n e$ in Portugal and Heterodera in Mediterranean France), and sedentary endoparasites were not detected on A. arenaria in Poland (Table 2).

The number of feeding generalist nematodes were significantly higher $(P<0.05)$ in Europe and South Africa than in New Zealand, while numbers in the USA and Tasmania were intermediate (replicates listed in Table 2). Distinct from the patterns for feeding specialists, some feeding generalists were present at all locations of the native range, but the identity of the species representing that genus, for example Helicotylenchus, differed among locations; in Poland, Helicotylenchus multicinctus was detected, in The Netherlands Helicotylenchus pseudorobustus, and in Portugal we found a species of Helicotylenchus that has not yet been described. Therefore, the data on feeding specialists and feeding generalists are in support of feeding-specialist hypothesis (2), but the lower number of feeding-specialist nematode taxa in the margins of the native range reduces the strength of the comparison.

Comparison of nematodes of Ammophila arenaria and similar plant species in introduced ranges

The comparison between the total number of root-feeding nematode taxa on native, similar plant species and on $A$. arenaria showed data points that were scattered around the 1:1 line (Figure 2a). In the introduced range, there were not significantly fewer nematode taxa on $A$. arenaria than on similar native species $\left(t_{8}=0.45\right.$, $P=0.667)$. This result is identical to the native range, where $A$. arenaria did not have fewer 
Table 1. Plant-feeding nematode families, taxa, and their feeding type in the root zone of pure Ammophila arenaria stands in natural and introduced ranges.

\begin{tabular}{|c|c|c|}
\hline Suborder: family & Taxon & $\begin{array}{l}\text { Feeding type (after Yeates } \\
\text { et al. 1993) }\end{array}$ \\
\hline Hoplolaimina: Heteroderidae & $\begin{array}{l}\text { Heterodera arenaria Cooper, } 1955 \\
\text { Heterodera } \text { sp. } \\
\text { Heteroderidae (juveniles) }\end{array}$ & $\begin{array}{l}\text { Sedentary endoparasite } \\
\text { Sedentary endoparasite } \\
\text { Sedentary endoparasite }\end{array}$ \\
\hline Hoplolaimina: Meloidogynidae & $\begin{array}{l}\text { Meloidogyne maritima Jepson, } 1987 \\
\text { Meloidogyne sp. }\end{array}$ & $\begin{array}{l}\text { Sedentary endoparasite } \\
\text { Sedentary endoparasite }\end{array}$ \\
\hline Hoplolaimina: Pratylenchidae & $\begin{array}{l}\text { Pratylenchus brzeskii Karssen, Waeyenberge \& Moens, } 2000 \\
\text { Pratylenchus penetrans (Cobb, 1917) } \\
\text { Pratylenchus scribneri Steiner, 1943 } \\
\text { Pratylenchus sp. }\end{array}$ & $\begin{array}{l}\text { Migratory endoparasite } \\
\text { Migratory endoparasite } \\
\text { Migratory endoparasite } \\
\text { Migratory endoparasite }\end{array}$ \\
\hline Tylenchina: Anguinidae & Ditylenchus sp. & Ectoparasite \\
\hline Hoplolaimina: Hoplolaimidae & $\begin{array}{l}\text { Rotylenchus sp. } \\
\text { Helicotylenchus pseudorobustus (Steiner, 1914) } \\
\text { Helicotylenchus depressus Yeates, } 1967 \\
\text { Helicotylenchus multicinctus (Cobb, 1893) } \\
\text { Helicotylenchus sp. a } \\
\text { Helicotylenchus sp. b }\end{array}$ & $\begin{array}{l}\text { Ectoparasite } \\
\text { Ectoparasite } \\
\text { Ectoparasite } \\
\text { Ectoparasite } \\
\text { Ectoparasite } \\
\text { Ectoparasite }\end{array}$ \\
\hline Hoplolaimina: Tylenchorhynchidae & $\begin{array}{l}\text { Telotylenchus ventralis (Loof, 1963) } \\
\text { Telotylenchus sp. } \\
\text { Neodolichorhynchus microphasmis (Loof, 1960) } \\
\text { Neodolichorhynchus dubius (Butschli, 1873) } \\
\text { Neodolichorhynchus sp. } \\
\text { Merlinius sp. }\end{array}$ & $\begin{array}{l}\text { Ectoparasite } \\
\text { Ectoparasite } \\
\text { Ectoparasite } \\
\text { Ectoparasite } \\
\text { Ectoparasite } \\
\text { Ectoparasite }\end{array}$ \\
\hline Hoplolaimina: Belonolaimidae & $\begin{array}{l}\text { Morulaimus geniculatus Sauer, } 1966 \\
\text { (syn. Scutellonema magnum Yeates, } 1967\end{array}$ & Ectoparasite \\
\hline Hoplolaimina: Dolichodoridae & Neodolichodorus arenarius (Clark, 1963) & Ectoparasite \\
\hline Criconematina: Criconematidae & Criconema sp. & Ectoparasite \\
\hline Criconematina: Paratylenchidae & $\begin{array}{l}\text { Paratylenchus microdorus Andrassy, } 1959 \\
\text { Paratylenchus sp. }\end{array}$ & $\begin{array}{l}\text { Ectoparasite } \\
\text { Ectoparasite }\end{array}$ \\
\hline Criconematina: Hemicycliophoridae & $\begin{array}{l}\text { Hemicycliophora halophila Yeates, } 1967 \\
\text { Hemicycliophora obesa Thorne, } 1955 \\
\text { Hemicycliophora sp. }\end{array}$ & $\begin{array}{l}\text { Ectoparasite } \\
\text { Ectoparasite } \\
\text { Ectoparasite }\end{array}$ \\
\hline Dorylaimina: Longidoridae & $\begin{array}{l}\text { Longidorus kuiperi Brinkman, Loof \& Barbez, } 1987 \\
\text { Longidorus sp. }\end{array}$ & $\begin{array}{l}\text { Ectoparasite } \\
\text { Ectoparasite }\end{array}$ \\
\hline Diphtherophorina: Trichodoridae & $\begin{array}{l}\text { Paratrichodorus lobatus (Colbran, 1965) } \\
\text { (syn. Trichodorus clarki Yeates, 1967) } \\
\text { Trichodorus sp. }\end{array}$ & $\begin{array}{l}\text { Ectoparasite } \\
\text { Ectoparasite }\end{array}$ \\
\hline
\end{tabular}

nematode taxa than adjacent Poaceae $\left(t_{4}=1.84\right.$, $P=0.9298$; Figure 2a). Therefore, when considering all nematode taxa, the native species hypothesis (3) is rejected. Further analysis may elucidate to which extent $A$. arenaria has escaped from most its native species of root-feeding nematodes, but it obviously is not exposed to fewer nematode taxa in the introduced range.
The native species hypothesis (3) was only marginally rejected when testing for feedingspecialist (sedentary endoparasitic) nematodes $\left(t_{8}=-1.84, \quad P=0.0519 ; \quad\right.$ Figure $\left.2 \mathrm{~b}\right)$. In this case, feeding specialist taxa were not found on $A$. arenaria in most introduced regions, except in the USA. In Tasmania, there were cyst nematodes detected in the root zone of the native 


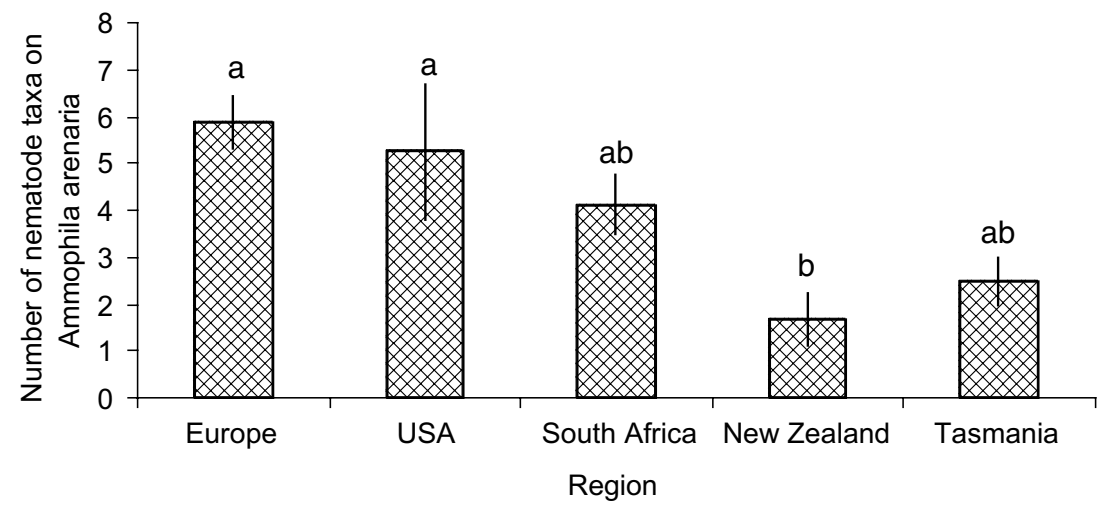

Figure 1. Average number of plant-feeding nematode taxa ( \pm standard error) in the root zone of pure Ammophila arenaria stands in natural and introduced ranges in five regions.

grass Spinifex sp., but not on $A$. arenaria. In the natural range, $A$. arenaria did not have fewer feeding specialist nematode taxa than native plant species adjacent in the successional gradient $\left(t_{4}=2.14, P=0.9503\right.$; Figure 2b).

The native species hypothesis (3) was rejected when comparing number of generalist feeding nematodes on $A$. arenaria and native plants in the introduced range $\left(t_{8}=0.78, P=0.772\right)$. Therefore, $A$. arenaria did not have fewer generalist feeding (migratory endoparasite and ectoparasite) nematode taxa than similar native plant species in the introduced range. In the natural range, A. arenaria also did not have fewer generalist feeding nematode taxa than adjacent Poaceae in the successional gradient in coastal foredunes $\left(t_{4}=1.41, P=0.8849\right.$; Figure $\left.2 \mathrm{c}\right)$.

The issue of sampling intensity around grasses in natural and introduced locations

We determined the cumulative number of plantfeeding nematode taxa found in the roots or in the root zone sand of $A$. arenaria and two grasses in a natural sampling location in The Netherlands (Figure 3a). While the cumulative number of nematode taxa of the inner dune species $C$. epigejos was fairly constant over time, the cumulative number of nematode taxa on the beach grass Elymus farctus and on $A$. arenaria steadily increased with increased sampling (Figure 3a).

The total number of nematode taxa isolated each month shows some fluctuation during the sampling period (Figure 3b). At peak plant growth (August) there were 3 (for $A$. arenaria and $E$. farctus) or 4 (C. epigejos) fewer taxa recorded than the total number of taxa found over the entire growing season (Figure 3a). Therefore, in general, for these three plant species a single sampling event, as has carried out for most sampling locations in the introduced regions, would have yielded only 60-77\% (100* [number of nematode species in August divided by the total number of nematode species observed in 1 year]) of the actual nematode taxon diversity.

For Himatangi Beach, New Zealand, one rootfeeding nematode species (Morulaimus geniculatus) was present every month, while one (Hemicycliophora halophila) was present 4 out of 12 months and the other two (Dolichodorus arenarius and Criconematidae juveniles) were present occasionally and at very low densities. Moreover, $H$. halophila was only found below $30-\mathrm{cm}$ depth and would have been missed even given repeated sampling of the topsoil. Thus a single sampling would have the chance of missing $50-75 \%$ of all plant feeding nematode taxa present, but the same error was applied to locations in which we could control sampling intensity, by using data from peak growth season only. The exceptions to this sampling error are the literature records from Scotland and Poland, that might have produced an under- or overestimation owing to different sampling techniques, intensities, or sampling dates. 


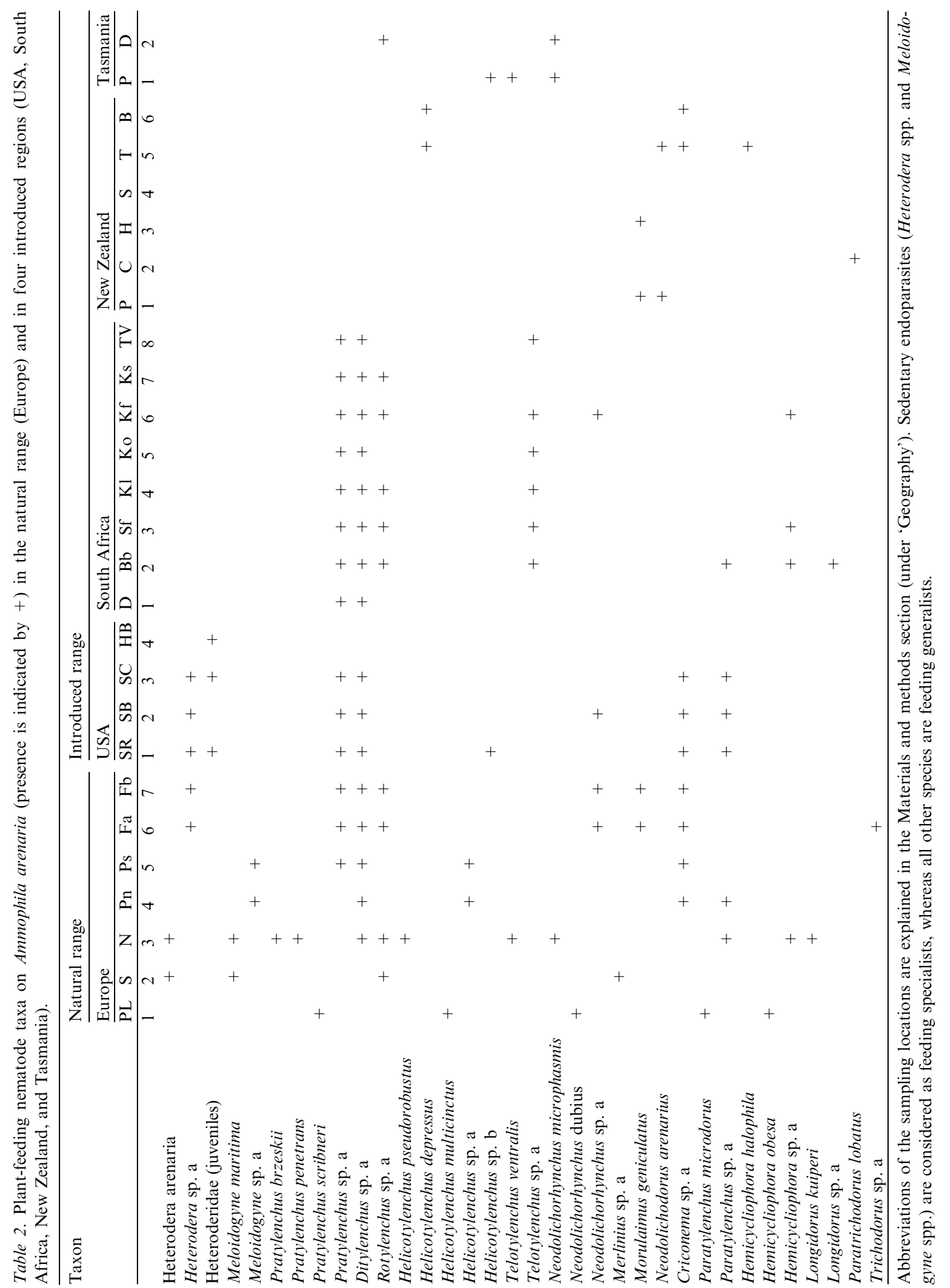



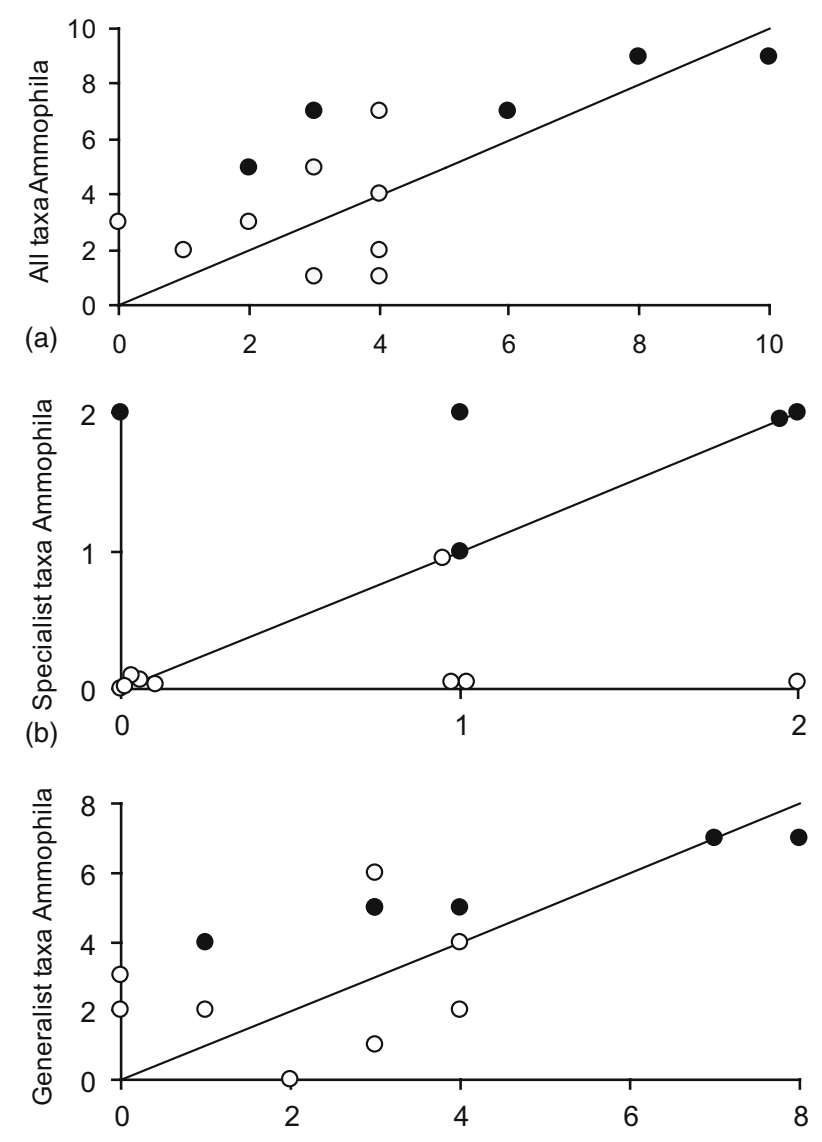

(c) No. generalist nematode taxa on native species

Figure 2. Number of plant-feeding nematode taxa on native plant species plotted against the number of plant-feeding nematode taxa on Ammophila arenaria. Closed symbols: natural range, open symbols: introduced range. (a) All plant-feeding nematodes, (b) specialist feeding types (sedentary endoparasitic Heterodera spp. and Meloidogyne spp. only); note that some data were offset to make individual data points visible and (c) generalist feeding types (ectoparasites) only.

\section{Discussion}

Mitchell and Power (2003) showed that invasive plants have fewer aboveground plant pathogen and virus species in their introduced than in natural ranges, and that invasive plants also had fewer of these pathogen species than did similar species native to the introduced ranges. Our results for root-feeding nematodes, however, did not fit into the general pattern observed for aboveground plant pathogens and viruses. Nevertheless, we found that specialist feeders (sedentary endoparasites) of $A$. arenaria were absent in the introduced regions in the southern hemisphere. This agrees with observations by Jobin et al. (1996) and Memmott et al. (2000), who found fewer specialist shoot-eating insects feeders on introduced than on native plants. In the light of this, we discuss the different hypotheses, whether invasive $A$. arenaria may have escaped its natural root-feeding nematodes, and how this may relate to the ecology of $A$. arenaria in natural and introduced regions.

On average, $A$. arenaria did not have more root-feeding nematode taxa in its natural range than in three out of four introduced regions worldwide. This leaves little support for our first hypothesis that an invasive plant may have fewer root-feeding nematode taxa in its introduced than in its natural range. The only marked reduction of the number of root-feeding nematodes was observed in New Zealand, where some classes, for 

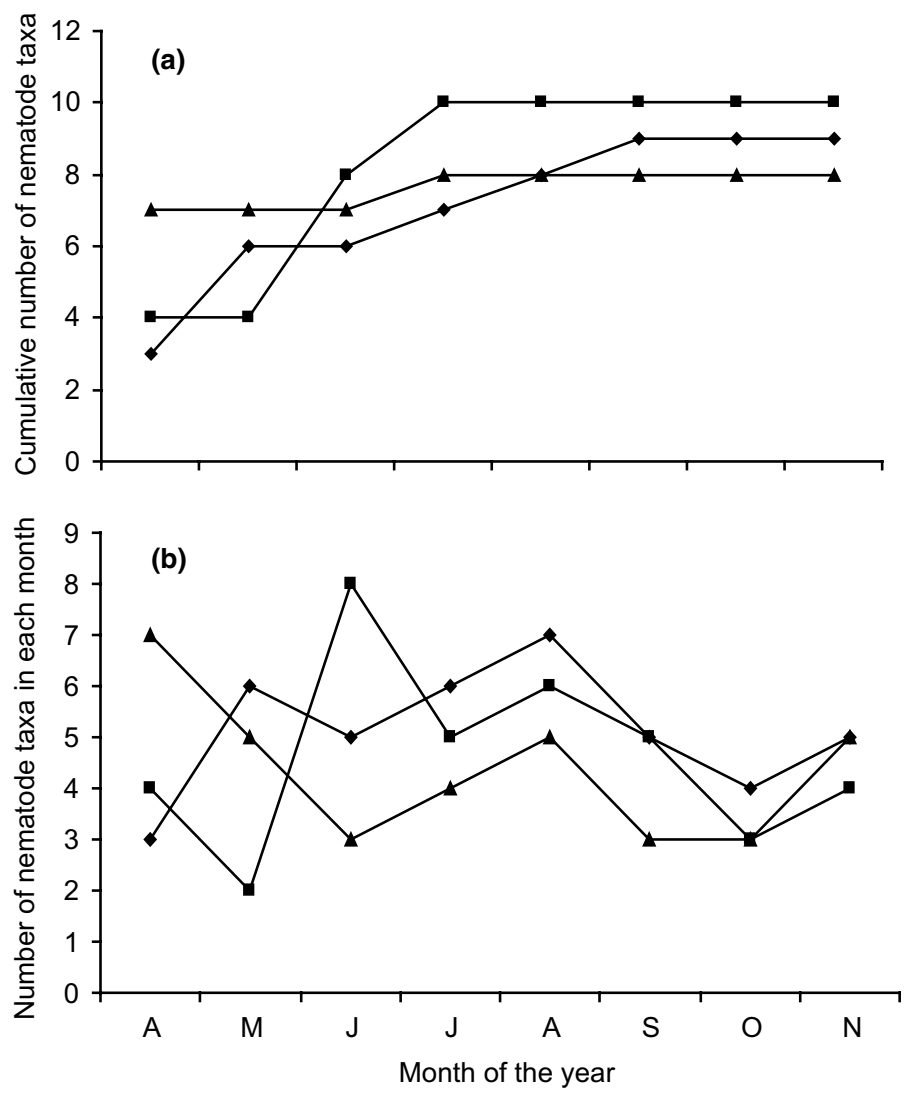

Figure 3. Number of plant-feeding nematode taxa on Ammophila arenaria $(\bullet)$, an earlier successional grass Elymus farctus (ם) and a later successional grass Calammagrostis epigejos $(\boldsymbol{\Delta})$, in dunes of the Netherlands. (a) Cumulative number of taxa since the start of monthly sampling; (b) average number of taxa at each sampling date.

example migratory endoparasitic nematodes, do not occur. The dominant native plant species in New Zealand foredunes was taxonomically quite distinct from the introduced species (in New Zealand, the dominant native species belonged to the Cyperaceae, while the introduced species belonged to the Poaceae). This conclusion confirms that of Knevel et al. (2004) who found less similarity between nematodes in the root zone of $A$. arenaria and South African foredune dicotyledonous plants than between A. arenaria and South African foredune grasses (Poaceae).

The second hypothesis was that in its introduced range $A$. arenaria would have fewer feeding specialists than in its natural range, similar to the situation for aboveground insects on some alien plant species (Jobin et al. 1996; Memmott et al. 2000). For our feeding-specialist taxa, we used the classification of nematode feeding types of Yeates et al. (1993) and considered sedentary endoparasitic nematodes feeding specialists because of their capacity to initiate feeding structures within plant roots. In South Africa, Tasmania, and New Zealand, $A$. arenaria had no specialist feeders (the sedentary, endoparasitic cyst and root knot nematodes), while in the USA we found cyst nematodes. Thus, in introduced regions in the southern hemisphere $A$. arenaria appeared to have escaped from both feeding specialist taxa, while in the USA plants had escaped from one feeding specialist nematode taxon. Therefore, our hypothesis on fewer feeding specialists on the invasive plant species is supported in the introduced regions in the southern hemisphere, but not in the introduced region in the northern hemisphere.

In general, A arenaria did not have fewer nematode taxa than similar native plant species 
in the introduced range, which is not in support of our third hypothesis. However, the comparison of feeding specialist taxa on $A$. arenaria and similar native species in the introduced range resulted into a close to significant effect, so that the native species hypothesis may be supported when considering feeding specialists, but not when considering feeding generalists.

In our field survey along the west coast of the USA, we also collected soil samples from Ammophila breviligulata, the American cogener of $A$. arenaria, natural to the east coast of North America/USA (Maun 1998). At Sunset Beach Road, Oregon, there was only one feeding specialist (Heterodera sp.) and one feeding generalist (Tylenchorhynchus; currently Neodolichorhynchus sp.), while at two locations in Delaware on the east coast of the USA, where A. breviligulata is natural, seven genera (of which at least one had two species) had been found; one sedentary, endoparasitic feeding specialist and six migratory, feeding generalists (Seliskar and Huettel 1993). This comparison might indicate an escape of $A$. breviligulata from its natural root-feeding nematode community, while $A$. breviligulata has not been reported to be exposed to Heterodera and Tylenchorhynchus spp. in its natural range, except in lacustrine dunes along the Great Lakes in Canada (Little and Maun 1996). However, the study by Seliskar and Huettel (1993) was more intensive than ours, and our repeated sampling throughout the year shows that one-time surveys may underestimate the actual diversity of rootfeeding nematodes in foredunes by $50-75 \%$. Nevertheless, the spectrum of nematode taxa to which $A$. breviligulata is exposed in its introduced range seems quite different from that in its natural range.

In a survey on pathogens on grasses, Clay (1995) concluded that the number of pathogen species increased with grass geographic range. This conclusion may also hold for root-feeding nematodes on A. arenaria, but patterns for feeding generalists and specialists appear to be in contrast. For example the ectoparasite (feeding generalist) genus Helicotylenchus. was represented by different species in the nortern, central, and southern locations of its natural range. The sedentary endoparasites (feeding specialists) Heterodera and Meloidogyne, on the other hand, were absent in the northern extreme, and in parts of the southern extreme of the natural range of A. arenaria. Therefore, the number of root-feeding nematode taxa increased with geographic range, while the number of (feeding-specialist) taxa per site decreased towards the margins of the natural range of the host plant.

In our comparison, we have averaged the number of taxa within sampling locations and considered sampling locations within geographic regions (Europe, USA, South Africa, Tasmania, and New Zealand) as replicates. However, if the number of feeding specialists is lower at the margins than in the centre of the geographic range, as it appears to be in Europe, then averaging the number of taxa within a geographic range may reduce the power of the analysis. Therefore, future analyses might also focus on taxon variation within and between natural and introduced regions or, alternatively, compare between natural and introduced regions with similar environmental conditions, for example climate and rainfall.

A feeding specialist may not necessarily be a host specialist. In north-western Europe, the feeding specialist Heterodera arenaria occurs on both A. arenaria in the mobile (yellow) dunes (Cooper and Harrison 1973; Cook 1982; Robinson et al. 1996; Clapp et al. 2000) and on the beach grass E. farctus (C.D. van der Stoel, W.H. van der Putten and H. Duyts, unpublished results). However, the feeding specialist Meloidogyne maritima occurs only on A. arenaria (Karssen et al. 1998a), while $M$. duytsi occurs only on E. farctus (Karssen et al. 1998b). Cross-inoculation studies show that $H$. arenaria multiplies on both plants (van der Stoel 2001), but that both M. maritima and M. duytsi seem more host specific (W.H. van der Putten and H. Duyts, unpublished results). While $H$. arenaria is not aggressively reducing the growth of its host plant (van der Stoel 2001), $M$. maritima does so, however, not in the presence of $H$. arenaria and $P$. penetrans (E.P. Brinkman et al., submitted for publication).

It is not only the number of pathogenic species left behind in the natural territory that is important, but that there should also be information on their role in the ecology of the invasive plants (Mitchell and Power 2003). Feeding specialist dune nematodes and feeding generalists show 
interspecific competition, but this did not appear to be strong enough to control the abundance of the nematodes (Brinkman et al. 2004). However, interspecific control among feeding specialist nematodes of $A$. arenaria points at non-linear effects of diversity of feeding specialists. Therefore, due to non-linear effects of nematode diversity on growth of $A$. arenaria (E.P. Brinkman et al., submitted for publication) the ecological consequences of reduced diversity of feeding specialist nematodes in the introduced regions cannot be directly interpreted as enemy release. On the other hand, abundance of most feeding types of nematodes in the root zone of $A$. arenaria (excluding $H$. arenaria) relates positively to growth reduction, so that reduced nematode abundance may indicate at enhanced plant invasiveness.

In natural dunes root-feeding nematodes are not the only cause of growth reduction of $A$. arenaria. Growth experiments with $A$. arenaria in South Africa (Knevel et al. 2004) and the USA (Beckstead and Parker 2003) have shown that the soils from these two introduced regions also produce growth-reducing potential even in the absence of feeding-specialist nematodes. These results are in agreement with studies in the natural range (van der Stoel et al. 2002), while field densities of feeding generalists were found to have little impact on plant biomass production (de Rooij-van der Goes 1995). Therefore, further understanding of $A$. arenaria invasiveness will require information on escape from other soil enemies as well, such as pathogenic soil fungi.

Our study shows that plants may escape from their feeding-specialist natural root-feeding nematodes, but that they have a high chance of becoming exposed to almost as many feeding generalist nematode taxa in their introduced range. In the analysis made by Mitchell and Power (2003), A. arenaria would fit in the category of 'intensively used plants'. These plant species had more aboveground pathogens than plants that were not intensively used. Mitchell and Power (2003) suggested that their study on aboveground pathogens and viruses may stand as a model for belowground pathogens, but that suggestion needs further verification. However, our analysis suggests that the escape pattern of invasive plants from root-feeding nematodes may be more similar to the pattern observed for aboveground herbivorous insects (Memmott et al. 2000). Our study shows that comparisons between natural enemies on invasive plants in natural and introduced ranges requires full coverage of the entire natural and non-natural ranges, as the number of feeding-specialist nematode taxa seemed lower in the extremes than in the central part of the natural range. Future studies may need to include comparisons between, as well as within natural and introduced ranges. Data on numbers of nematode taxa on invasive plants in their natural and introduced regions are an indication of enemy escape, but the ultimate test requires that the ecological consequences of the reduced root-feeders load needs to be quantified. This does not only apply to root feeders, but also to aboveground feeders.

\section{Acknowledgements}

We thank Roy Lubke and Brad Ripley for introducing WvdP to South African sand dunes and for collecting the soil samples in the USA, Kate Lessells for collecting the soil samples in the Camarque and Emma Watt for collecting the samples in Tasmania. This study has been performed as part of the EU-INVASS project and the EU-EcoTrain project (contracts IC18CT970145 and HPRN-CT-2002-00210 with the European Commission). An ISAT grant from the Royal Society of New Zealand facilitated writing of this paper.

\section{References}

Beckstead J and Parker IM (2003) Invasiveness of Ammophila arenaria: release from soil-borne pathogens? Ecology 84: 2824-2831

Bever JD (1994) Feedback between plants and their soil communities in an old field community. Ecology 75: 1965-1977

Bever JD (2003) Soil community feedback and the coexistence of competitors: conceptual frameworks and empirical tests. New Phytologist 157: 465-473

Blossey B and Hunt-Joshi TR (2003) Belowground herbivory by insects: influence on plants and aboveground herbivores. Annual Review of Entomology 48: 521-547

Bongers T (1988) De nematoden van Nederland. Stichting Uitgeverij Koninklijke Nederlandse Natuurhistorische Vereniging, Utrecht, Nederland 
Brinkman EP, van Veen JA and van der Putten WH (2004) Plant recruitment of endoparasitic nematodes may influence, but not regulate, ectoparasitic nematodes. Applied Soil Ecology 27: 65-75

Brown VK and Gange AC (1992) Secondary plant succession how is it modified by insect herbivory. Vegetatio 101: 3-13

Brzeski MW (1998) Nematodes of Tylenchina in Poland and temperate Europe. Muzeum i Instytut Zoologii Polska Akademia Nauk, Warszawa, Poland, 397 pp

Buell AC, Pickart AJ and Stuart JD (1995) Introduction history and invasion patterns of Ammophila arenaria on the north coast of California. Conservation Biology 9: $1587-1593$

Callaway RM, DeLuca TH and Belliveau WM (1999) Biological-control herbivores may increase competitive ability of the noxious weed Centaurea maculosa. Ecology 80: 1196-1201

Clapp JP, van der Stoel CD and van der Putten WH (2000) Rapid identification of cyst (Heterodera spp., Globodera spp.) and root-knot (Meloidogyne spp.) nematodes on the basis of ITS2 sequence variation detected by PCR-SSCP (PCR-Single-Strand Conformational Polymorphism) in cultures and field samples. Molecular Ecology 9: 1223-1232

Clark SE, van Driesche RG, Sturdevant $\mathrm{N}$ and Kegly $\mathrm{S}$ (2001b) Effect of root feeding insects on spotted knapweed (Centaurea maculosa) stand density. Southwestern Entomologist 26: 129-135

Clark SE, van Driesche RG, Sturdevant N, Elkinton J and Buonaccorsi JP (2001a) Effects of site characteristics and release history on establishment of Agapeta zoegana (Lepidoptera: Cochylidae) and Cyphocleonus achates (Coleoptera: Curculionidae), root-feeding herbivores of spotted knapweed, Centaurea maculosa. Biological Control 22: $122-130$

Clay K (1995) Correlates of pathogen species richness in the grass family. Canadian Journal of Botany 73 (Suppl. 1AD): S42-S49

Cook R (1982) Cereal and grass hosts of some gramineous cyst nematodes. EPPO Bulletin 12: 99-411

Cooper BA (1955) A preliminary key to British species of Heterodera for use in soil examinations. In: McE Kevan DK (ed) Soil Zoology, pp 269-280. Butterworths Scientific Publications, London

Cooper JI and Harrison BD (1973) The role of weed hosts and the distribution and activity of vector nematodes in the ecology of tobacco rattle virus. Annals of Applied Biology 73: 53-66

De Deyn GB, Raaijmakers CE, Zoomer HR, Berg MP, De Ruiter PC, Verhoef HA, Bezemer TM and van der Putten WH (2003) Soil invertebrate fauna enhances grassland succession and diversity. Nature 422: 711-713

De Rooij-van der Goes PCEM (1995) The role of plant-parasitic nematodes and soil-borne fungi in the decline of Ammophila arenaria (L.) Link. New Phytologist 129: 611669

Hertling UM and Lubke RA (1999) Use of Ammophila arenaria for dune stabilisation in South Africa and its current distribution - perceptions and problems. Environtal Management 24: 467-482
Hertling UM and Lubke RA (2000) Assessing the potential for biological invasion - the case of Ammophila arenaria in South Africa. South African Journal of Science 96: 520-527

Heyligers PC (1985) The impact of introduced plants on foredune formation in south-east Australia. Proceedings of the Ecological Society of Australia 14: 23-41

Huiskes AHL (1979) Biological flora of the British Isles: Ammophila arenaria $(\mathrm{L}$.) Link (Psamma arenaria $(\mathrm{L}$.) Roem. et Schult.: Calamagrostis arenaria (L.) Roth). Journal of Ecology 67: 363-382

Jobin A, Schaffner U and Nentwig W (1996) The structure of the phytophagous insect fauna on the introduced weed Solidago altissima in Switzerland. Entomologia Experimentalis et Applicata 79: 33-42

Karssen G, van Aelst A and Cook R (1998a) Redescription of the root-knot nematode Meloidogyne maritima Jepson, 1987 (Nematoda: Heteroderidae), a parasite of Ammophila arenaria (L.) Link. Nematologica 44: 241-253

Karssen G, van Aelst A and van der Putten WH (1998b) Description of Meloidogyne duytsi $\mathrm{n}$. sp. (Nematoda: Heteroderidae), a root-knot nematode from Dutch coastal foredunes. Fundamental and Applied Nematology 21: 299-306

Keane RM and Crawley MJ (2002) Exotic plant invasions and the enemy release hypothesis. Trends in Ecology and Evolution 17: 164-170

Kisiel M (1970) On the systematic and geographical distribution of the nematodes inhabiting sand dunes in an Ammophila arenaria plant community. Zeszyty Naukowe Wyszej Szkoly Rolniczej w Szczecinie 34: 151-193

Kliromonos JN (2002) Feedback with soil biota contributes to plant rarity and invasiveness in communities. Nature 417: $67-70$

Knevel IC, Lans T, van der Putten WH, Menting FBJ and Hertling UM (2004) The role of the enemy release hypothesis and the biotic resistance hypothesis in the establishment of the alien Ammophila arenaria in South Africa. Oecologia 141: $502-510$

Levine JM, Vila M, D'Antonio CM, Dukes JS, Grigulis K and Lavorel S (2003) Mechanisms underlying the impacts of exotic plant invasions. Proceedings of the Royal Society of London, Series B, Biological Sciences 270: 775-781

Little LR and Maun MA (1996) The 'Ammophila problem' revisited: a role for mycorrhizal fungi. Journal of Ecology 84: $1-7$

Liebhold AM, MacDonald WL, Bergdahl D and Mastro VC (1995) Invasion by Exotic Forest Pests: A Threat to Forest Ecosystems. Forest Science Monograph (No. 30): ii +49 pp. Society of American Foresters, Bethesda, MD

Maun MA (1998) Adaptations of plants to burial in coastal sand dunes. Canadian Journal of Botany 76: 713-738

Memmott J, Fowler SV, Paynter Q, Sheppard, AW and Syrett P (2000) The invertebrate fauna on broom, Cytisus scoparius, in two native and two exotic habitats. Acta Oecologia 21: 213-222

Mitchell CE and Power AG (2003) Release of invasive plants from fungal and viral pathogens. Nature 421: 625-627

Owen SJ (1996) Ecological Weeds on Conservation Land in New Zealand: A Database. Department of Conservation, Wellington, New Zealand, 118 pp 
Packer A and Clay K (2000) Soil pathogens and spatial patterns of seedling mortality in a temperate tree. Nature 404: 278-281

Packer A and Clay K (2002) Soil pathogens and Prunus serotina seedlings and sapling growth near conspecific trees. Ecology 84: 108-119

Pimentel D (2002) Biological Invasions: Economic and Environmental Costs of Alien Plant, Animal, and Microbe Species. CRC Press, Boca Raton, FL, 369 pp

Reinhart KO, Packer A, van der Putten WH and Clay K (2003) Plant-soil biota interactions and spatial distribution of black cherry in its native and invasive ranges. Ecology Letters 6: 1046-1050

Rejmanek M and Richardson DM (1996) What attributes make some plants more invasive? Ecology 77: 1665-1661

Robinson AF, Orr CC and Abernathy JR (1978) Distribution of Nothanguina phyllobia and its potential as a biological control agent for silver-leaf nightshade. Journal of Nematology 10: 362-366

Robinson AJ, Stone AR, Hooper DJ and Rowe JA (1996) A redescription of Heterodera arenaria Cooper 1955, a cyst nematode from marram grass. Fundamental and Applied Nematology 19: 109-117

Seliskar DM and Huettel RN (1993) Nematode involvement in die-out of Ammophila breviligulata (Poaceae) on the Mid-Atlantic coastal dunes. Journal of Coastal Research 9: 97-103

Stanton NL (1988) The underground in grasslands. Annual Review of Ecology and Systematics 19: 573-589

Torchin ME, Lafferty KD, Dobson AP, McKenzie VJ and Kuris AM (2003) Introduced species and their missing parasites. Nature 421: 628-630

van der Putten WH (2003) Plant defense below ground and spatio-temporal processes in natural vegetation. Ecology 84: 2269-2280

van der Putten WH and van der Stoel CD (1998) Plant parasitic nematodes and spatio-temporal variation in natural vegetation. Applied Soil Ecology 10: 253-262

van der Putten WH, van Dijk C and Peters BAM (1993) Plant-specific soil-borne diseases contribute to succession in foredune vegetation. Nature 362: 53-56

van der Stoel CD (2001) Specificity, Pathogenicity and Population Dynamics of the Endoparasitic Nematode Hedero- dera arenaria in Coastal Foredunes. $\mathrm{PhD}$ thesis Wageningen University, The Netherlands

van der Stoel CD, van der Putten WH and Duyts H (2002) Development of a negative plant-soil feedback in the expansion zone of the clonal grass Ammophila arenaria following root formation and nematode colonisation. Journal of Ecology 90: 978-988

Verschoor BC, De Goede RGM, De Vries FW and Brussaard L (2001) Changes in the composition of the plant-feeding nematode community in grasslands after cessation of fertiliser application. Applied Soil Ecology 17: 1-17

Virginia RA, Jarell WM, Whitford WG and Freckman DW (1992) Soil biota and soil properties in the surface rooting zone of mesquite (Prosopis glandulosa) in historical and recently desertified Chihuahuan Desert habitats. Biology and Fertility of Soils 14: 90-98

Wall JW, Skene KR and Neilson R (2002) Nematode community and trophic structure along a sand dune succession. Biology and Fertility of Soils 4: 293-301

Wardle DA (2002) Communities and Ecosystems: Linking the Aboveground and Belowground Components. Princeton University Press, Princeton, NJ

Wiedemann AM and Pickart AJ (1996) The Ammophila problem on the Northwest Coast of North America. Landscape and Urban Planning 34: 287-299

Williamson M (1996) Biological Invasions. Chapman \& Hall, London

Yeates GW (1967) Studies on nematodes from dune sands. 9. Quantitative comparison of the nematode faunas of six localities. New Zealand Journal of Science 10: 927-948

Yeates GW (1968) An analysis of annual variation of the nematode fauna in dune sand, at Himatangi Beach, New Zealand. Pedobiologia 8: 173-207

Yeates GW (1999) Effects of plants on nematode community structure. Annual Review of Phytopathology 37: 127-149

Yeates GW and Williams PA (2001) Influence of three invasive weeds and site factors on soil microfauna in New Zealand. Pedobiologia 45: 367-383

Yeates GW, Bongers T, De Goede RGM, Freckman DW and Georgieva SS (1993) Feeding habits in soil nematode families and genera - an outline for soil ecologists. Journal of Nematology 25: 315-331 